\title{
Manganese Fluorene Phosphonates: Formation of Isolated Chains
}

\author{
Clarisse Bloyet ${ }^{1}$ (i) , Jean-Michel Rueff ${ }^{1, *}$, Vincent Caignaert ${ }^{1}$, Bernard Raveau ${ }^{1}$, \\ Jean-François Lohier $^{2}$ (D), Mélissa Roger ${ }^{3}$, Guillaume Rogez 4 (i) and Paul-Alain Jaffrès ${ }^{3, *}$ (iD \\ 1 Normandie Univ, ENSICAEN, UNICAEN, CNRS, CRISMAT, 14000 Caen, France; \\ clarisse.bloyet@ensicaen.fr (C.B.); vincent.caignaert@ensicaen.fr (V.C.); raveau@ensicaen.fr (B.R.) \\ 2 Normandie Univ, ENSICAEN, UNICAEN, CNRS, LCMT, 6 Bd du Maréchal Juin, 14050 Caen CEDEX, \\ France; jean-francois.lohier@ensicaen.fr \\ 3 CEMCA UMR CNRS 6521, Université de Brest, IBSAM, 6 Avenue Victor Le Gorgeu, 29238 Brest, France; \\ roger.melissa@outlook.fr \\ 4 IPCMS, UMR Unistra-CNRS 7504, 23 rue du Loess, BP 43, 67034 Strasbourg CEDEX 2, France; \\ Guillaume.Rogez@ipcms.unistra.fr \\ * Correspondence: jean-michel.rueff@ensicaen.fr (J.-M.R.); Paul-Alain.Jaffres@univ-brest.fr (P.-A.J.)
}

Received: 17 July 2018; Accepted: 3 September 2018; Published: 5 September 2018

\begin{abstract}
: 9,9-dimethylfluorenyl-2-phosphonic acid 1 was reacted with manganese nitrate tetrahydrate to produce under hydrothermal conditions the crystalline manganese phosphonate $\mathrm{Mn}\left(\mathrm{H}_{2} \mathrm{O}\right)_{2}\left[\mathrm{O}_{2}(\mathrm{OH}) \mathrm{PC}_{15} \mathrm{H}_{13}\right]_{2} \cdot 2 \mathrm{H}_{2} \mathrm{O}$ which crystallize in the $P 2_{1} / c$ space group. This compound is a rare example of $\mathrm{Mn}$-phosphonate material featuring isolated chains. The interactions between these chains containing the 9,9-dimethylfluorenyl moieties, result from Van der Waals interactions involving the fluorene ligands and $\mathrm{C} \cdots \mathrm{H}-\mathrm{C}$ hydrogen bonds as revealed by Hirshfeld Surfaces. This material features antiferromagnetic exchange interactions as revealed by the magnetic susceptibility as a function of the temperature.
\end{abstract}

Keywords: metal-phosphonate; fluorene; magnetism; hybrid material

\section{Introduction}

The chemistry of metal phosphonates [1], which was started more than forty years ago with the discovery of zirconium layered compounds [2,3], is nowadays an important basis for the realization of hybrid organic-inorganic materials. For this purpose, phosphonic acids constitute the common organic precursors for the preparation of hybrid materials that can be subdivided in three categories depending on the methods used for their preparation: via hydrothermal synthesis [4], via intercallation [5] and by surface modification of inorganic materials [6]. The versatility of the synthesis of phosphonic acid [7] offers a large panel of organic precursors and their structure can be adapted to produce hybrid materials with specific properties: luminescence [8,9], porosity [10], non-linear optics [11], catalysis [12-15], molecular recognition [16,17], ion exchanges properties [18], bactericidal action [19] via metal ions release [20] or magnetic properties [21]. The crystalline transition metal phosphonates offer large possibilities for the realization of new structures, by playing with the nature and the number of phosphonate functions, which generate the organic part of the hybrid. In this direction we focused our research on the use of organic precursors featuring a phosphonic acid directly connected to an aromatic [22,23] or heteroaromatic [24] ring thus producing rigid phosphonic acids. This rigidity associated with the presence of additional functionalities (e.g., carboxylic acid) influenced the structure of the final hybrid materials [25]. More recently, we and others [26-28] explored fluorene as a new rigid aromatic backbone for the synthesis of hybrid 
structures via hydrothermal synthesis $[29,30]$ or by intercalation in layered inorganic materials [5]. In the series of manganese-phosphonate hybrids we noticed that only few structures that incorporate non-functionalized phosphonic acid were reported. The first $\mathrm{Mn}$ (II) series deals with the alkyl and phenyl monophosphates $\mathrm{Mn}\left(\mathrm{O}_{3} \mathrm{PC}_{n} \mathrm{H}_{2 n+1}\right) \cdot \mathrm{H}_{2} \mathrm{O}$ and $\mathrm{Mn}\left(\mathrm{O}_{3} \mathrm{PC}_{6} \mathrm{H}_{5}\right) \cdot \mathrm{H}_{2} \mathrm{O}$ synthesized by Mallouk et al. [31], which were shown by the authors to exhibit a layered structure built up of inorganic

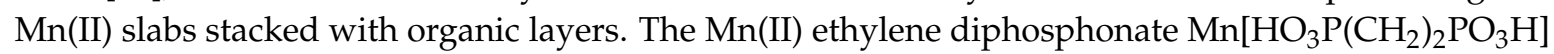
reported by Cheetham et al. [32] also exhibits a layered structure, whose inorganic slabs involving dimeric octahedral manganese units, which are interconnected through ethylene diphosphonate ligands. A third diphosphonate with a layered structure has been synthesized by Rueff et al. [24], using the thiophene diphosphonic acid for the construction of this hybrid. The structure of this $\mathrm{Mn}(\mathrm{II})$ thiophene diphosphonate $\mathrm{Mn}_{2}\left(\mathrm{O}_{3} \mathrm{P}-\mathrm{C}_{4} \mathrm{H}_{2} \mathrm{~S}-\mathrm{PO}_{3}\right) \cdot 2 \mathrm{H}_{2} \mathrm{O}$ consists of perovskite-like layers of $\mathrm{MnO}_{6}$ octahedrons pillared through thiophene diphosphonate groups. The $\mathrm{Mn}$ (II) dimethylbenzene diphosphonate $\mathrm{Mn}\left(\mathrm{H}_{2} \mathrm{O}\right)_{2}\left(\mathrm{HPO}_{3} \mathrm{C}_{8} \mathrm{H}_{8} \mathrm{PO}_{3} \mathrm{H}\right) \cdot 2 \mathrm{H}_{2} \mathrm{O}$ recently synthesized by Tang et al. [33], is to our knowledge the only manganese phosphonate prepared from non-functional phosphonic acids that exhibits a chain structure involving chains of corner-shared $\mathrm{MnO}_{6}$ octahedrons and $\mathrm{PO}_{3} \mathrm{C}$ tetrahedrons interconnected through dimethylbenzene diphosphonate groups.

The above results suggest that the nature of the phosphonic or diphosphonic acid alone dictates the structure of the so synthesized phosphonates, especially the arrangement of the manganese polyhedra and their mode of connection either between them or with the $\mathrm{PO}_{3} \mathrm{C}$ tetrahedral, either as layers or as chains for instance. Thus, we have investigated the possibility to synthesize new manganese phosphonate using 9,9-dimethylfluorenyl-2-phosphonic acid $\mathbf{1}$ as organic precursor, shown in Scheme 1.

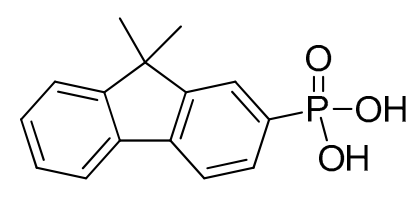

1

Scheme 1. Chemical structure of the organic ligand 9,9-dimethylfluorenyl-2-phosphonic acid 1 used for the synthesis of manganese phosphonate $\mathrm{Mn}\left(\mathrm{H}_{2} \mathrm{O}\right)_{2}\left[\mathrm{O}_{2}(\mathrm{OH}) \mathrm{PC}_{15} \mathrm{H}_{13}\right]_{2} \cdot 2 \mathrm{H}_{2} \mathrm{O}$.

The present paper reports the synthesis, structure and magnetic characterization of the mono-phosphonate $\mathrm{Mn}\left(\mathrm{H}_{2} \mathrm{O}\right)_{2}\left[\mathrm{O}_{2}(\mathrm{OH}) \mathrm{PC}_{15} \mathrm{H}_{13}\right]_{2} \cdot 2 \mathrm{H}_{2} \mathrm{O}$ showing a chain structure.

\section{Results and Discussion}

\subsection{Structural Study}

The manganese phosphonates $\mathrm{Mn}\left(\mathrm{H}_{2} \mathrm{O}\right)_{2}\left[\mathrm{O}_{2}(\mathrm{OH}) \mathrm{PC}_{15} \mathrm{H}_{13}\right]_{2} \cdot 2 \mathrm{H}_{2} \mathrm{O}$ was obtained as monophasic polycrystalline samples, as shown from its powder $\mathrm{X}$-ray pattern that was indexed with the cell parameters obtained from the single crystal studies, seen in Figure S1.

For this mono-phosphonate which crystallizes in the $P 2_{1} / c$ space group (Table 1 ), the atomic coordinates (see Table S1) combined with the thermogravimetric analysis (Figure S2) and the bond valence sum calculations according to Altermat and Brown [34] (see Table S2) confirm that manganese is in a divalent state. It also clearly establish the presence of one hydrogen atom on the $\mathrm{O} 2$ and $\mathrm{O} 5$ oxygen of the phosphorus coordination sites and of two hydrogen atoms on the $\mathrm{O} 7$ and O8 oxygen of the manganese environment. $\mathrm{Mn}(\mathrm{II})$ exhibits a six-fold coordination forming $\mathrm{MnO}_{4}\left(\mathrm{H}_{2} \mathrm{O}\right)_{2}$ octahedrons, whereas the phosphonate groups form $\mathrm{PO}_{2}(\mathrm{OH}) \mathrm{C}$ tetrahedra. The $\mathrm{Mn}-\mathrm{O}$ and $\mathrm{P}-\mathrm{O}$ distances (Table S3) are observed in the range 2.144 to $2.233 \AA$ and 1.502 to $1.587 \AA$, respectively; while a P-C distance close to $1.80 \AA$ is obtained, in agreement with the values generally reported for other phosphonates. 
Table 1. Crystallographic data of $\mathrm{Mn}\left(\mathrm{H}_{2} \mathrm{O}\right)_{2}\left[\mathrm{O}_{2}(\mathrm{OH}) \mathrm{PC}_{15} \mathrm{H}_{13}\right]_{2} \cdot 2 \mathrm{H}_{2} \mathrm{O}$ recorded at $150 \mathrm{~K}$.

\begin{tabular}{cc}
\hline Formula & $\mathbf{M n}\left(\mathbf{H}_{\mathbf{2}} \mathbf{O}_{2} \mathbf{2}_{\mathbf{2}} \mathbf{O}_{\mathbf{2}}(\mathbf{O H}) \mathbf{P C} \mathbf{1}_{\mathbf{1 5}} \mathbf{H}_{\mathbf{1 3}}\right]_{\mathbf{2}} \cdot \mathbf{2} \mathbf{H}_{\mathbf{2}} \mathbf{O}$ \\
\hline $\mathrm{FW}$ & 673.486406 \\
Space group & $P 2_{1} / c$ \\
$a(\AA)$ & $9.3882(4)$ \\
$b(\AA)$ & $37.3410(16)$ \\
$c(\AA)$ & $9.2398(4)$ \\
$\alpha\left(^{\circ}\right)$ & 90.000 \\
$\beta\left(^{\circ}\right)$ & 90.000 \\
$\gamma\left({ }^{\circ}\right)$ & 90.000 \\
$Z$ & 4 \\
$V\left(\AA^{3}\right)$ & $3239.15(24)$ \\
$\mathrm{d}_{\text {calc }}\left(\mathrm{g} / \mathrm{cm}^{3}\right)$ & 1.30498 \\
$\mu\left(\mathrm{mm}^{-1}\right)$ & 0.551 \\
radiation source $\lambda(\AA)$ & $\mathrm{Ko} \alpha 0.71073$ \\
Pattern range $2 \Theta\left(^{\circ}\right)$ & $4.86-61.02$ \\
no. of reflexions & 42391 \\
no. of soft constraints & 3 \\
$R\left[F^{2}>2 \sigma\left(F^{2}\right)\right]$ & 0.0452 \\
$R_{\text {int }}($ internal $R$-value $)$ & 0.0308 \\
$S($ Goodness of the fit) & 1.051 \\
\hline
\end{tabular}

The projections of the structure of this hybrid along $c$ in Figure $1 \mathrm{a}$ and $b$ in Figure $1 \mathrm{~b}$ show its one-dimensional character. Each $\mathrm{Mn}$ (II) octahedron shares four $\mathrm{O}$ apices with four different $\mathrm{P}$ tetrahedrons and has two free $\mathrm{H}_{2} \mathrm{O}$ apices (Figure 1a,b) forming infinite chains, whereas each $\mathrm{P}$ tetrahedron has one free $\mathrm{OH}$ apex. The chains are displayed in the form of layers parallel to the (010) plane and exhibit a zigzag configuration along $a$ in Figure $1 \mathrm{~b}$. The organic ligands form layers parallel to (010) in Figure 1a, but the orientation of the dimethyl fluorene ligands within these layers in Figure 1c is different from that generally observed in other layered or chain manganese-based phosphonates: they show a cross-like configuration characterized by an angle close to $90^{\circ}\left(88.316^{\circ}\right)$ between two successive ligands. However such type of orientation was reported in other metal-phosphonate materials $[26,30]$. The orientation of the fluorene moieties with respect to the inorganic chains is essentially governed by the presence of $[\mathrm{Mn}, \mathrm{P}] \mathrm{O} \cdots \mathrm{H}-\mathrm{C}$ and $\mathrm{P}-\mathrm{O} \cdots \mathrm{H}-\mathrm{C}$ hydrogen bonds, illustrated in the grey dashed lines in Figure 1a, that take place between the fluorene groups and the chain. The latter exhibit $\mathrm{O} \cdots \mathrm{H}$ distances ranging from 2.559 to $2.836 \AA$ and from 2.683 to $2.732 \AA$, respectively. The cohesion of the structure, i.e., the stability of the assemblage of the chains is ensured by two kinds of bonds: Van der Waals bonds between the fluorene ligands of two different chains, and C $\cdots \mathrm{H}-\mathrm{C}$ bonds between the fluorene of two different chains, shown by the light blue dashed lines in Figure 1a, with $\mathrm{C} \cdots \mathrm{H}$ distances ranging from 2.720 to $3.179 \AA$ A. Note that $\mathrm{C} \cdots \mathrm{H}-\mathrm{C}$ bonds between two fluorene ligands of the same inorganic chain are also observed (plum dashed lines in Figure 1a), with $\mathrm{C} \cdots \mathrm{H}$ distances ranging from 2.819 to $3.193 \AA$. It is worth pointing out that all the hydrogen bonds which participate to the stability of the structure have not been described here, due to the fact that positions of the hydrogen atoms of the $\mathrm{H}_{2} \mathrm{O}$ molecules (free water molecules and $\mathrm{H}_{2} \mathrm{O}$ labeled $\mathrm{O} 8$ and $\mathrm{O} 7$ of the $\mathrm{MnO}_{4}\left(\mathrm{H}_{2} \mathrm{O}\right)_{2}$ octahedron) could not be determined, as mentioned above. 


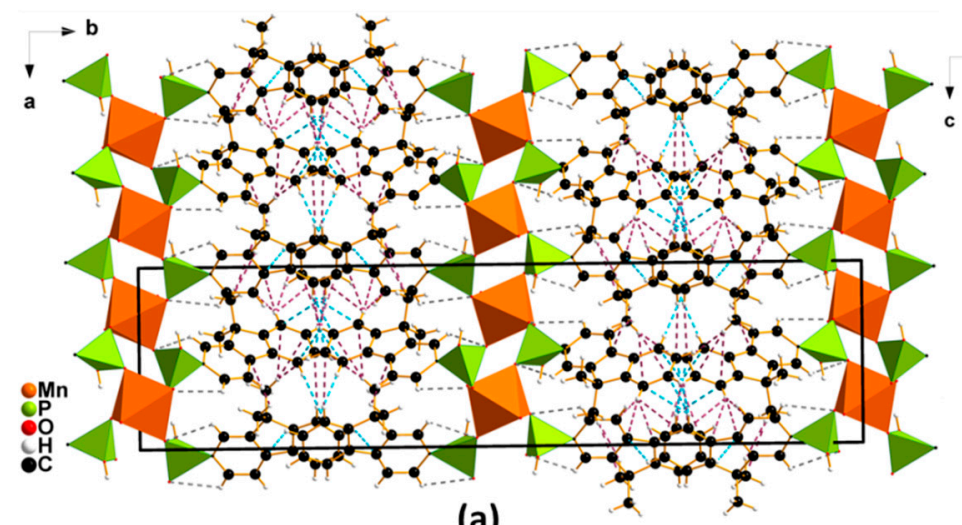

(a)

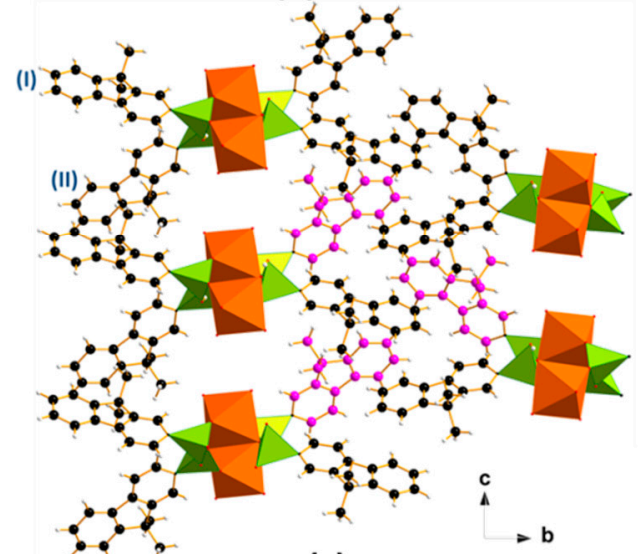

(c)

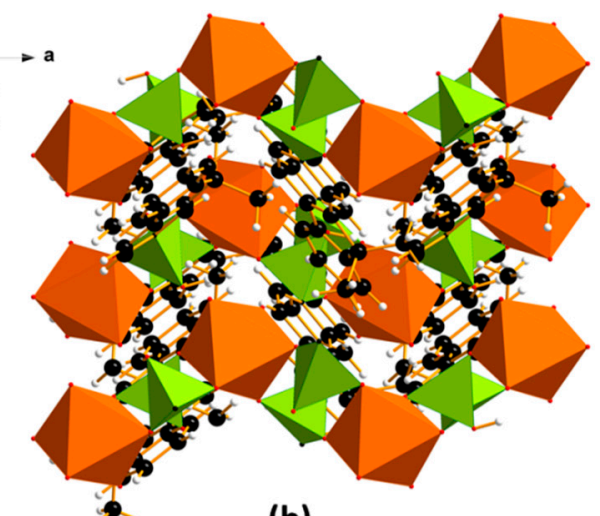

(b)

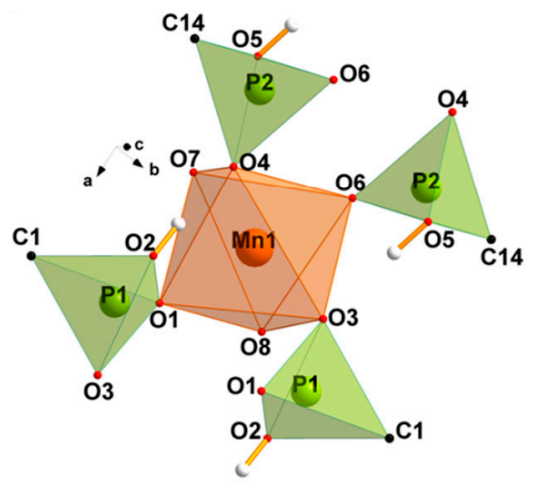

(d)

Figure 1. Structure of the monophosphate $\mathrm{Mn}\left(\mathrm{H}_{2} \mathrm{O}\right)_{2}\left[\mathrm{O}_{2}(\mathrm{OH}) \mathrm{PC}_{15} \mathrm{H}_{13}\right]_{2} \cdot 2 \mathrm{H}_{2} \mathrm{O}$ : (a) projection along $c$ with the representation of intra-columnar and inter-columnar $\mathrm{C}-\mathrm{H} \cdots \mathrm{C}$ bonds in plum and light blue dashed lines, respectively, the $\mathrm{O} \cdots \mathrm{H}-\mathrm{C}$ bonds are represented by grey dashed lines. The black square represent the cell edge; (b) projection along $b$; (c) View along $a$ showing the cross-like configuration of fluorene ligands around one inorganic chain. The notations (I) and (II) correspond to the different orientations of the organic part. The carbon atoms colored pink present weak $\pi-\pi$ interactions with an angle of $32^{\circ}$ between two conjugated rings of the orientation I. (d) Representation of the manganese environment within the chain structure.

\subsection{Hirshfeld Surfaces, 2D-Fingerprint Plots and Crystal Voids Properties}

In order to obtain a rapid visual and a brief summary of the intermolecular interactions that are at the origin of the molecular arrangement in those materials, Hirshfeld surfaces (HS) $[35,36]$ and two-dimensional fingerprint plots [37] were generated using the CrystalExplorer program [38]. For the calculations, manganese atoms and water molecules were not taken in account. The HS envelope the dimethyl fluorene phosphonate moiety of the monophosphonate $\mathrm{Mn}\left(\mathrm{H}_{2} \mathrm{O}\right)_{2}\left[\mathrm{O}_{2}(\mathrm{OH}) \mathrm{PC}_{15} \mathrm{H}_{13}\right]_{2} \cdot 2 \mathrm{H}_{2} \mathrm{O}$. They were calculated in very high resolution using an isosurface of the weight function $w(r)=0.5$, where $w(r)$ corresponds to the sum of all spherical atom $(A)$ electron densities from the molecule observed divided by the analogous sum for the whole molecules of the crystal (Equation (1)):

$$
w(r)=\frac{\sum_{A \in \text { molecule }} \rho_{A}(r)}{\sum_{A \in \text { crystal }} \rho_{A}(r)}
$$

From each point of the isosurface, two distances, $d_{i}$ and $d_{e}$, are determined, which correspond to the distance from the closest atom inside the molecule to the surface or from the latter to the nearest atom of another molecule, respectively. Besides, to highlight areas corresponding to different intermolecular interactions, a normalized contact distance mode $\left(d_{n o r m}\right)$ was mapped onto the HS, as seen in Figure 2. 
The latter combines $d_{i}$ and $d_{e}$ distances which are both normalized by the Van der Waals (VdW) radii of the two atoms implicated in the close contact to the surface, shown in Equation (2):

$$
d_{\text {norm }}=\frac{d_{i}-r_{i}^{V d W}}{r_{i}^{V d W}}+\frac{d_{e}-r_{e}^{V d W}}{r_{e}^{V d W}}
$$

All HS are shown as transparent in order to visualize the impact of the close contact between the observed moiety and its neighbor for different orientations. Red spots represent distances shorter than the sum of VdW radii and correspond to $\mathrm{O} \cdots \mathrm{H}$ bonds. Blue and white regions correspond to distances close to or longer than the sum of $\mathrm{VdW}$ radii, respectively. The principal areas of some intermolecular interactions are represented by different geometric and colored forms: light blue corresponds to the $\mathrm{H} \cdots \mathrm{H}$ bonds and yellow to $\mathrm{C} \cdots \mathrm{H}$ bonds.

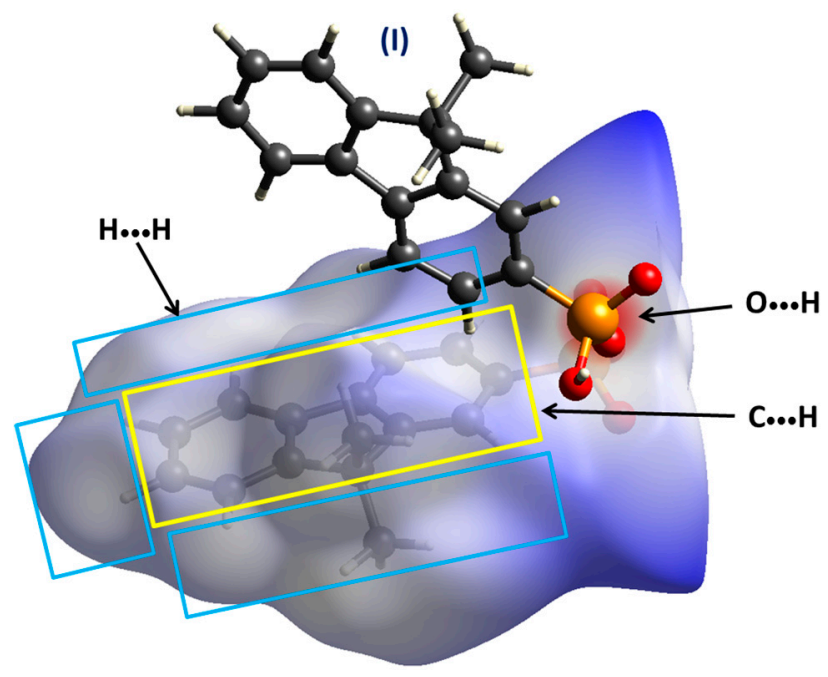

Figure 2. Hirshfeld surface represented on the dimethyl fluorene phosphonate $\left[\mathrm{C}_{15} \mathrm{H}_{13}-\mathrm{PO}_{2}(\mathrm{OH})\right]$ part of $\mathrm{Mn}\left(\mathrm{H}_{2} \mathrm{O}\right)_{2}\left[\mathrm{O}_{2}(\mathrm{OH}) \mathrm{PC}_{15} \mathrm{H}_{13}\right]_{2} \cdot 2 \mathrm{H}_{2} \mathrm{O}$ with $d_{\text {norm }}$ property mapped onto the surface. For orientations (I) and (II), intermolecular interactions are present in the same principal areas. Color code: red-white-blue corresponding to distances shorter than, close to or longer than the sum of VdW radii, respectively. Pictures generated with CrystalExplorer software [38].

The shape index mapping S, shown in Equation (3), allows the observation of the principal curves $\left(\kappa_{1}, \kappa_{2}\right)$ on the surface shape of the dimethyl fluorene part, such as complementary bumps (blue spots) and hollows (red spots) which are observed when two molecular surfaces are in contact. The presence of the pattern formed by spread blue and red triangles in the same area reveals the existence of weak $\pi-\pi$ interactions in the dimethyl fluorene moieties, as seen in Figure 3, as it was also reported in other metal phosphonate [39]. In this compound weak $\pi-\pi$ interactions with an angle of $32^{\circ}$ between two conjugated rings (pink colored, orientation I) are observed in Figure 1c. They correspond to $\mathrm{C}-\mathrm{H} \cdots \mathrm{C}$ distances of $3.605 \AA$ A between two moieties.

$$
\mathrm{S}=\frac{2}{\pi} \arctan \left(\frac{\kappa_{1}+\kappa_{2}}{\kappa_{1}-\kappa_{2}}\right)
$$




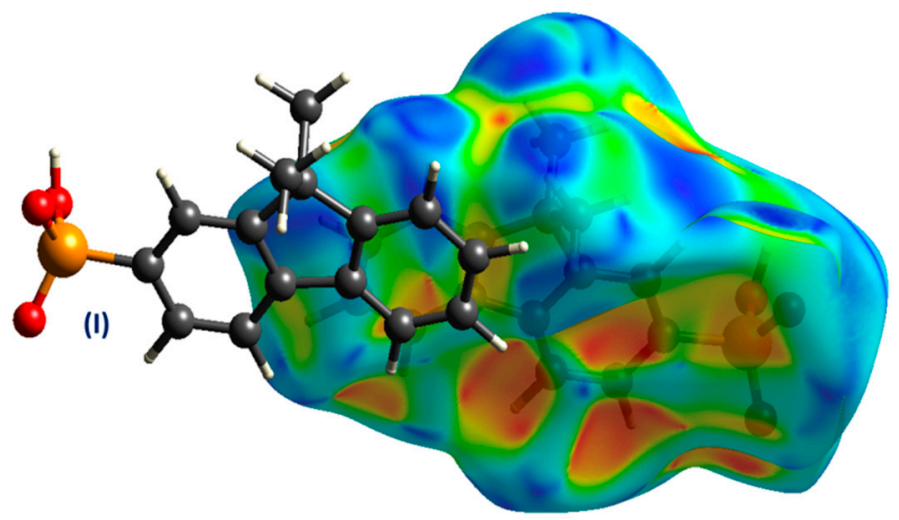

Figure 3. Hirshfeld surface represented on the dimethyl fluorene phosphonate part $\left[\mathrm{C}_{15} \mathrm{H}_{13}-\mathrm{PO}_{2}(\mathrm{OH})\right]$ of $\mathrm{Mn}\left(\mathrm{H}_{2} \mathrm{O}\right)_{2}\left[\mathrm{O}_{2}(\mathrm{OH}) \mathrm{PC}_{15} \mathrm{H}_{13}\right]_{2} \cdot 2 \mathrm{H}_{2} \mathrm{O}$ with shape index property mapped onto the surface. The patterns of spread red and blue triangles characteristic of weak $\pi-\pi$ interactions are observed on the HS surface. Pictures are generated with the CrystalExplorer software [38].

The two-dimensional fingerprint plots, obtained from $d_{i}-d_{e}$ data point, corresponding to both orientations of the dimethyl fluorene phosphonate moieties are depicted on Figure 4 and are indexed in Table 2. Both orientations of the mono-phosphonate have very similar fingerprint plots which are dominated by $\mathrm{H} \cdots \mathrm{H}$ contacts ranging from $41.8 \%$ to $42.2 \%$, by $\mathrm{O} \cdots \mathrm{H}$ contacts between phosphonate groups varying from $13.8 \%$ to $19.8 \%$ and finally, by $\mathrm{C} \cdots \mathrm{H}$ contacts ranging from $19.5 \%$ to $24.5 \%$. To have more details on the area of small intermolecular interactions present within the $\mathrm{Mn}\left(\mathrm{H}_{2} \mathrm{O}\right)_{2}\left[\mathrm{O}_{2}(\mathrm{OH}) \mathrm{PC}_{15} \mathrm{H}_{13}\right]_{2} \cdot 2 \mathrm{H}_{2} \mathrm{O}$ compound, fingerprint plots of each orientation are broken down into the different close contacts in supplementary materials, as seen in Figures S3 and S4.

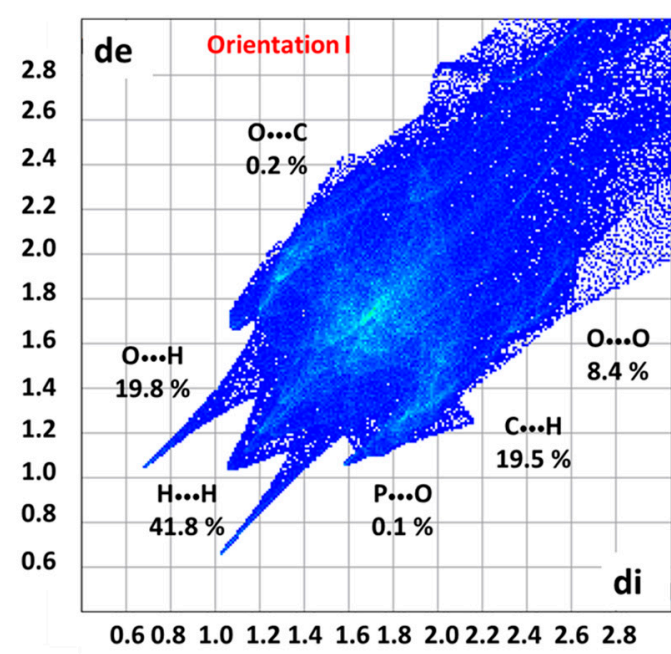

(a)

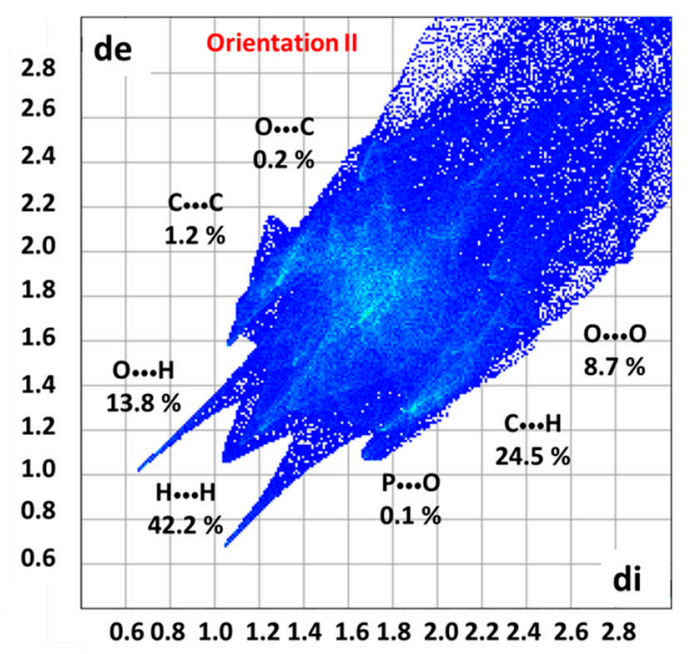

(b)

Figure 4. Two-dimensional fingerprint plots showing all intermolecular interactions with their overall percentage present in the different orientations of the organic part $\left[\mathrm{C}_{15} \mathrm{H}_{13}-\mathrm{PO}_{2}(\mathrm{OH})\right]$ of $\mathrm{Mn}\left(\mathrm{H}_{2} \mathrm{O}\right)_{2}\left[\mathrm{O}_{2}(\mathrm{OH}) \mathrm{PC}_{15} \mathrm{H}_{13}\right]_{2} \cdot 2 \mathrm{H}_{2} \mathrm{O}(\mathrm{a}$ and $\mathrm{b}) . d_{i}-d_{e}$ data points represent the closest distance from the Hirshfeld surface to the nearest atom inside the molecule itself $\left(d_{i}\right)$ or to the nearest atom of another molecule $\left(d_{e}\right)$. Manganese atoms are not taken into account in the calculations. Pictures are generated with the CrystalExplorer software [38]. 
Table 2. Contribution of the different intermolecular interactions in percentage present in a defined surface area on the different orientations of the $\left[\mathrm{C}_{15} \mathrm{H}_{13}-\mathrm{PO}_{2}(\mathrm{OH})\right]$ part of the hybrid material $\mathrm{Mn}\left(\mathrm{H}_{2} \mathrm{O}\right)_{2}\left[\mathrm{O}_{2}(\mathrm{OH}) \mathrm{PC}_{15} \mathrm{H}_{13}\right]_{2} \cdot 2 \mathrm{H}_{2} \mathrm{O}$.

\begin{tabular}{ccc}
\hline \multicolumn{3}{c}{$\left.\mathbf{M n}\left(\mathbf{H}_{\mathbf{2}} \mathbf{O}\right)_{\mathbf{2}}\left[\mathbf{O}_{\mathbf{2}} \mathbf{( O H}\right) \mathbf{P C}_{\mathbf{1 5}} \mathbf{H}_{\mathbf{1 3}}\right]_{\mathbf{2}} \cdot \mathbf{2} \mathbf{H}_{\mathbf{2}} \mathbf{O}$} \\
\hline Contact types (\%) & Orientation I & Orientation II \\
$\mathrm{P} \cdots \mathrm{O}$ & 0.1 & 0.1 \\
$\mathrm{O} \cdots \mathrm{O}$ & 8.4 & 8.7 \\
$\mathrm{O} \cdots \mathrm{C}$ & 0.2 & 0.2 \\
$\mathrm{O} \cdots \mathrm{H}$ & 19.8 & 13.8 \\
$\mathrm{C} \cdots \mathrm{C}$ & 0 & 1.2 \\
$\mathrm{C} \cdots \mathrm{H}$ & 19.5 & 24.5 \\
$\mathrm{H} \cdots \mathrm{H}$ & 41.8 & 42.2 \\
Sum & 89.8 & 90.7 \\
\hline
\end{tabular}

\subsection{Magnetic Properties}

The magnetic behavior of $\mathrm{Mn}\left(\mathrm{H}_{2} \mathrm{O}\right)_{2}\left[\mathrm{O}_{2}(\mathrm{OH}) \mathrm{PC}_{15} \mathrm{H}_{13}\right]_{2} \cdot 2 \mathrm{H}_{2} \mathrm{O}$ is represented on Figure 5 . The magnetic susceptibility $\chi$ increases continuously from $1.68 \times 10^{-2} \mathrm{emu} / \mathrm{mol}$ at $275 \mathrm{~K}$ to $0.58 \mathrm{emu} / \mathrm{mol}$ at $2 \mathrm{~K}$. The $\chi T$ product decreases from $4.63 \mathrm{emu} \cdot \mathrm{K} / \mathrm{mol}$ at $275 \mathrm{~K}$ to $1.15 \mathrm{emu} \cdot \mathrm{K} / \mathrm{mol}$ at $2 \mathrm{~K}$. The Curie constant, established from the high temperature fit (100-275 K) of the reverse of the susceptibility following the Curie-Weiss law is equal to $4.72 \mathrm{emu} \cdot \mathrm{K} / \mathrm{mol}$, in accordance with the expected value for $\mathrm{Mn}(\mathrm{II})$ ion $(4.37 \mathrm{emu} \cdot \mathrm{K} / \mathrm{mol}$, considering $g=2)$. The negative Weiss temperature, $\theta=-8.20 \mathrm{~K}$, suggest the presence of dominant antiferromagnetic exchange interactions. The $\chi=f(T)$ and $\chi T=f(T)$ curves of $\mathrm{Mn}\left(\mathrm{H}_{2} \mathrm{O}\right)_{2}\left[\mathrm{O}_{2}(\mathrm{OH}) \mathrm{PC}_{15} \mathrm{H}_{13}\right]_{2} \cdot 2 \mathrm{H}_{2} \mathrm{O}$ were simultaneously fit with the Boner-Fisher model [40] and leads to the following values: $g=2.05(2)$ and $J=-0.41(1) \mathrm{cm}^{-1}$.

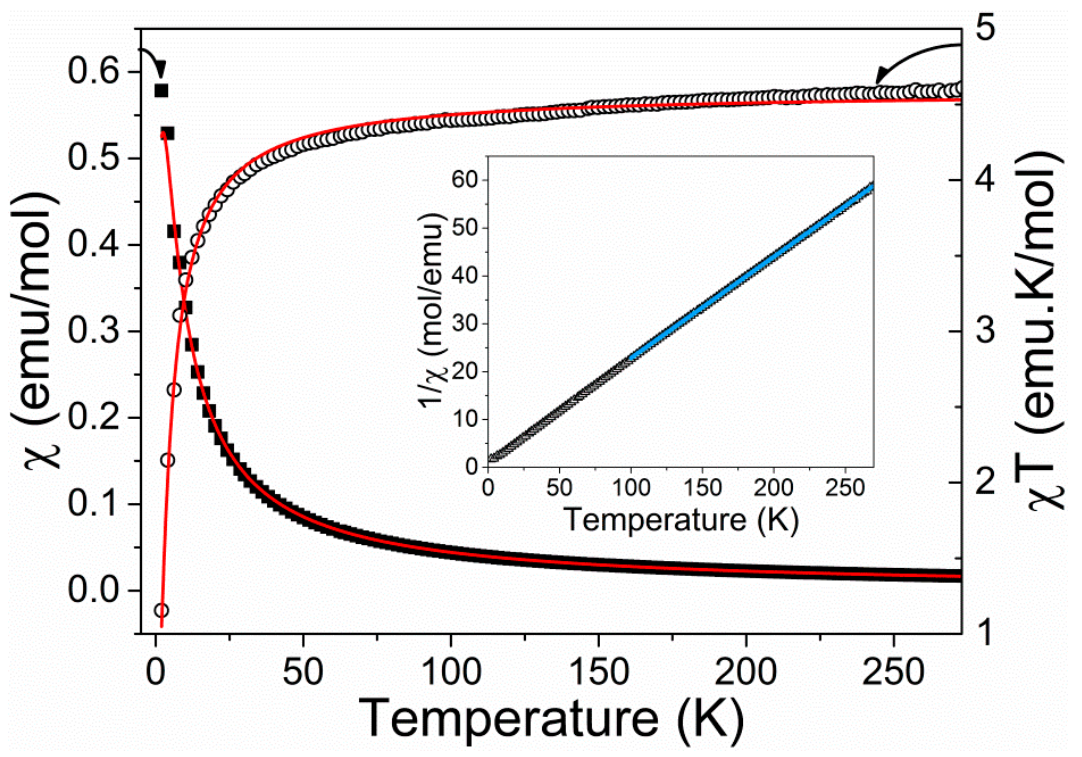

Figure 5. Variation of $\chi$ (black squares) and $\chi T$ (open black circles) as function of the temperature of $\mathrm{Mn}\left(\mathrm{H}_{2} \mathrm{O}\right)_{2}\left[\mathrm{O}_{2}(\mathrm{OH}) \mathrm{PC}_{15} \mathrm{H}_{13}\right]_{2} \cdot 2 \mathrm{H}_{2} \mathrm{O}$ under 1000 Oe. Inset: $1 / \chi$ versus $T$. The red and blue full lines correspond to the best fit of the experimental data with the Bonner-Fisher law and the Curie-Weiss law, respectively.

\section{Experimental Section}

\subsection{Materials and Methods}

Reagents and solvents were purchased from commercial sources. 9,9-dimethylfluorenyl-2-phosphonic acid was synthesized following a reported method [5]. Hydrothermal synthesis was carried out in 
Teflon-lined stainless-steel autoclaves under autogenous pressure. Powder X-ray diffraction patterns were obtained using a Panalytical X'Pert Pro MPD diffractometer (PANalytical, Almelo, The Netherlands) with $\mathrm{Cu} \mathrm{K} \alpha$ radiation. The Scanning Electron Microscopy (SEM) characterization was performed with a Carl ZEISS SUPRA 55 (Carl Zeiss Microscopy GmbH, Jena, Germany) on a raw sample with gold metallization. The energy dispersive X-ray spectrometry (EDS) analysis was performed with EDAX analyzer (AMETEK Materials Analysis Division, Mahwah, NJ, USA). The elemental analysis was carried out ThermoQuest NA2500 setup (THERMO FINNIGAN, Villebon sur Yvette, France). The thermogravimetric analysis was carried out under air atmosphere using a SETARAM TAG 92 apparatus (SETERAM Instrumentation, Caluire, France) at the heating rate of $3^{\circ} \mathrm{C}$ per minute from room temperature to $1000{ }^{\circ} \mathrm{C}$. The structural resolution was performed at $150 \mathrm{~K}$ by $X$-ray diffraction on single crystals using a Bruker-Nonius Kappa CCD area detector diffractometer with grafite-monochromatized Mo K $\alpha$ radiation $(\lambda=0.71073 \AA$ ). The crystal structure was solved by SHELXS-97 software (version 2017, George Sheldrick: Göttingen, Germany, 1997). The refinements were carried out with SHELXL-2014 (version 2017, George Sheldrick: Göttingen, Germany, 1997). Even if all cell angles are equal to $90^{\circ}$, the crystal structure can only be solved in the monoclinic system. There are several water molecules within the crystal, but due to important disorder, two free water molecules as well as hydrogen atoms from the water molecules (O7 and O8) of $\mathrm{MnO}_{4}\left(\mathrm{H}_{2} \mathrm{O}\right)_{2}$ octahedron could not be placed with accuracy, thus they have been omitted using the Squeeze instruction. In order to confirm or to detect $\mathrm{H}$ positions corresponding to $\mathrm{H}_{2} \mathrm{O}$ molecules or $\mathrm{OH}$ groups, bond valence sum calculations were performed by Valence software (version 2.00, I.D. Brown: Hamilton, ON, Canada, 1993). CCDC 1855208 contains the supplementary crystallographic data for this paper. These data can be obtained free of charge from The Cambridge Crystallographic Data Centre (http:/ / www.ccdc.cam.ac.uk/conts/retrieving.html).

\subsection{Synthesis of the Mono-Phosphonate $\mathrm{Mn}\left(\mathrm{H}_{2} \mathrm{O}\right)_{2} \mathrm{CO}_{2}(\mathrm{OH}) \mathrm{PC}_{15} \mathrm{H}_{13} \mathrm{I}_{2} \cdot 2 \mathrm{H}_{2} \mathrm{O}$}

A $50 \mathrm{~mL}$ polytetrafluoroethylene (PTFE) liner was filled with an equimolar mixture composed of manganese nitrate tetrahydrate $\mathrm{Mn}\left(\mathrm{NO}_{3}\right)_{2} \cdot 4 \mathrm{H}_{2} \mathrm{O}(0.046 \mathrm{~g}, 0.182 \mathrm{mmol})$, 9,9-dimethylfluorenyl2-phosphonic acid $\mathrm{C}_{15} \mathrm{H}_{15} \mathrm{O}_{3} \mathrm{P}$ (0.050 g, $\left.0.182 \mathrm{mmol}\right)$, shown in Scheme 1, dissolved in $15 \mathrm{~mL}$ of distillated water. Then, the liner was inserted in a Berghof DAB-2 digestive vessel and heated from room temperature to $140{ }^{\circ} \mathrm{C}$ in $20 \mathrm{~h}$, kept at this temperature for $30 \mathrm{~h}$ and finally allowed to cool to room temperature within $20 \mathrm{~h}$. The final product $\mathrm{Mn}\left(\mathrm{H}_{2} \mathrm{O}\right)_{2}\left[\mathrm{O}_{2}(\mathrm{OH}) \mathrm{PC}_{15} \mathrm{H}_{13}\right]_{2} \cdot 2 \mathrm{H}_{2} \mathrm{O}$, obtained as light brown parallelepiped single crystals, was filtered on Büchner, washed with distilled water, rinsed with ethanol and finally dried in air. The chemical formula was confirmed by CHNS analysis for $\mathrm{MnH}_{36} \mathrm{O}_{10} \mathrm{P}_{2} \mathrm{C}_{30}$ : found (\%): C 53.52, H 5.42, calc. (\%): C 53.50, H 5.38 and by energy-dispersive X-ray spectroscopy: $\mathrm{Mn}_{\mathrm{K}}=32.87, \mathrm{P}_{\mathrm{K}}=67.13$.

\subsection{Thermogravimetric Analysis}

Thermogravimetric analysis (TGA) was performed on polycrystalline sample of $\mathrm{Mn}\left(\mathrm{H}_{2} \mathrm{O}\right)_{2}\left[\mathrm{O}_{2}\right.$ $\left.(\mathrm{OH}) \mathrm{PC}_{15} \mathrm{H}_{13}\right]_{2} \cdot 2 \mathrm{H}_{2} \mathrm{O}$ under air atmosphere in order to study the water weight losses of these compounds as a function of the temperature. As shown on Figure S2, this material reveals a mass loss of $11.02 \%$ at $115.6{ }^{\circ} \mathrm{C}$ corresponding to the loss of four water molecules present within the structure (theoretical value: $10.70 \%$ ).

\subsection{Scanning Electron Microscopy}

The homogeneous batches of $\mathrm{Mn}\left(\mathrm{H}_{2} \mathrm{O}\right)_{2}\left[\mathrm{O}_{2}(\mathrm{OH}) \mathrm{PC}_{15} \mathrm{H}_{13}\right]_{2} \cdot 2 \mathrm{H}_{2} \mathrm{O}$ have been identified as parallelepiped shape single crystals with an average length of $298.50 \mu \mathrm{m}$, width of $153.85 \mu \mathrm{m}$ and an average thickness of $79.92 \mu \mathrm{m}$, as seen in Figure 6. 


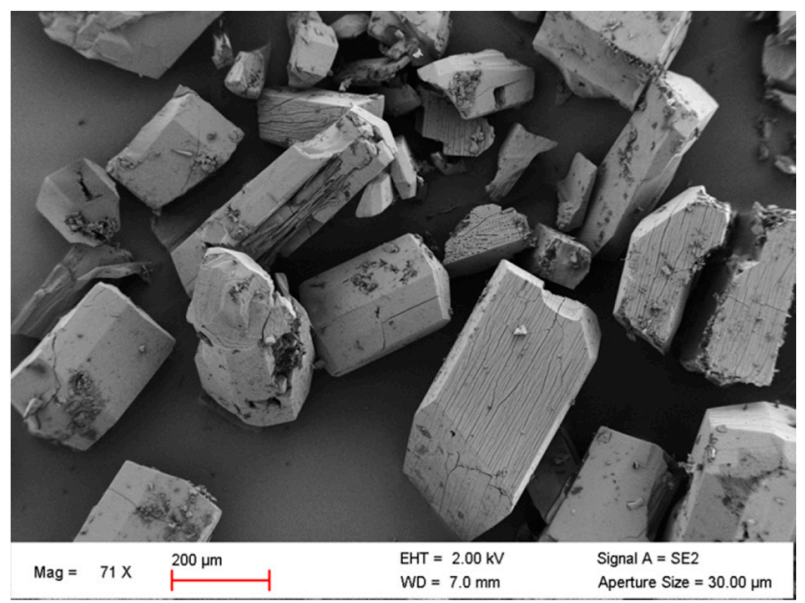

Figure 6. SEM image of showing the morphology of $\mathrm{Mn}\left(\mathrm{H}_{2} \mathrm{O}\right)_{2}\left[\mathrm{O}_{2}(\mathrm{OH}) \mathrm{PC}_{15} \mathrm{H}_{13}\right]_{2} \cdot 2 \mathrm{H}_{2} \mathrm{O}$.

\section{Conclusions}

The synthesis of crystalline hybrid materials from monophosphonic acids and manganese salts has been rarely studied in the literature. In the present case we designed 9,9-dimethylfluorenyl-2-phosphonic acid which feature a flat backbone on which two methyl groups and the phosphonic acid function present atoms that are not belong to the aromatic plane. This singular molecular structure produces a rigid organic building unit that likely governs the structure of the final crystalline hybrid structure. The originality of the hybrid $\mathrm{Mn}\left(\mathrm{H}_{2} \mathrm{O}\right)_{2}\left[\mathrm{O}_{2}(\mathrm{OH}) \mathrm{PC}_{15} \mathrm{H}_{13}\right]_{2} \cdot 2 \mathrm{H}_{2} \mathrm{O}$ comes from the presence of inorganic chains chains. These chains interact together via supramolecular interactions (van de Waals and $\mathrm{C} \cdot \mathrm{H}-\mathrm{C}$ hydrogen bonds) and exhibit an antiferromagnetic behavior at low temperature. This study points out that the association of rigid backbone with phosphonic acid function produces an organic building block of interest that offers original crystalline hybrids.

Supplementary Materials: The following are available online at http://www.mdpi.com/2304-6740/6/3/ 92/s1, Figure S1: X-ray diffraction data recorded on powder from $\mathrm{Mn}\left(\mathrm{H}_{2} \mathrm{O}\right)_{2}\left[\mathrm{O}_{2}(\mathrm{OH}) \mathrm{PC}_{15} \mathrm{H}_{13}\right]_{2} \cdot 2 \mathrm{H}_{2} \mathrm{O}$. Figure S2: Thermogravimetric analysis curves of $\mathrm{Mn}\left(\mathrm{H}_{2} \mathrm{O}\right)_{2}\left[\mathrm{O}_{2}(\mathrm{OH}) \mathrm{PC}_{15} \mathrm{H}_{13}\right]_{2} \cdot 2 \mathrm{H}_{2} \mathrm{O}$ recorded under air atmosphere from room temperature to $1000{ }^{\circ} \mathrm{C}$. Table S1: Atomic coordinates and thermal parameters of $\mathrm{Mn}\left(\mathrm{H}_{2} \mathrm{O}\right)_{2}\left[\mathrm{O}_{2}(\mathrm{OH}) \mathrm{PC}_{15} \mathrm{H}_{13}\right]_{2} \cdot 2 \mathrm{H}_{2} \mathrm{O}$. Table S2: Bond valence sum of $\mathrm{Mn}\left(\mathrm{H}_{2} \mathrm{O}\right)_{2}\left[\mathrm{O}_{2}(\mathrm{OH}) \mathrm{PC}_{15} \mathrm{H}_{13}\right]_{2} \cdot 2 \mathrm{H}_{2} \mathrm{O}$. Table S3: Interatomic distances of $\mathrm{Mn}\left(\mathrm{H}_{2} \mathrm{O}\right)_{2}\left[\mathrm{O}_{2}(\mathrm{OH}) \mathrm{PC}_{15} \mathrm{H}_{13}\right]_{2} \cdot 2 \mathrm{H}_{2} \mathrm{O}$. Figure S3: Fingerprint plots of $\mathrm{Mn}\left(\mathrm{H}_{2} \mathrm{O}\right)_{2}\left[\mathrm{O}_{2}(\mathrm{OH}) \mathrm{PC}_{15} \mathrm{H}_{13}\right]_{2} \cdot 2 \mathrm{H}_{2} \mathrm{O}$ highlighting the different intermolecular interactions with their percentage of contribution on the orientation $\mathrm{I}$ of the organic sub-network. Figure S4: Fingerprint plots of $\mathrm{Mn}\left(\mathrm{H}_{2} \mathrm{O}\right)_{2}\left[\mathrm{O}_{2}(\mathrm{OH}) \mathrm{PC}_{15} \mathrm{H}_{13}\right]_{2} \cdot 2 \mathrm{H}_{2} \mathrm{O}$ highlighting the different intermolecular interactions with their percentage of contribution on the orientation II of the organic sub-network. Cif and Check cif files of $\mathrm{Mn}\left(\mathrm{H}_{2} \mathrm{O}\right)_{2}\left[\mathrm{O}_{2}(\mathrm{OH}) \mathrm{PC}_{15} \mathrm{H}_{13}\right]_{2} \cdot 2 \mathrm{H}_{2} \mathrm{O}$.

Author Contributions: Conceptualization, P.-A.J., J.-M.R., C.B. and B.R.; Validation, all the authors; Formal Analysis, J.-F.L., C.B., V.C., M.R., J.-M.R., P.-A.J.; Writing-Original Draft Preparation, B.R., C.B., P.-A.J.; Writing-Review \& Editing, all authors equally contribute; Visualization, C.B.; Project Administration, G.R., P.-A.J., J.-M.R.; Funding Acquisition, G.R., P.-A.J., J.-M.R.

Funding: This research was funded by the Agence Nationale de la Recherche, grant number (ANR-14-CE07-0004-01-HYMN).

Acknowledgments: The authors also express their grateful acknowledgment to Sylvie Collin and Fabien Veillon for technical support and to Nicolas Barrier for helpful discussion (CRISMAT laboratory).

Conflicts of Interest: The authors declare no conflict of interest. The funders had no role in the design of the study; in the collection, analyses, or interpretation of data; in the writing of the manuscript, and in the decision to publish the results.

\section{References}

1. Clearfield, A.; Demadis, K. Metal Phosphonate Chemistry: From Synthesis to Applications; Royal Society of Chemistry: Cambridge, UK, 2011; ISBN 978-1-84973-356-4. 
2. Alberti, G.; Costantino, U.; Allulli, S.; Tomassini, N. Crystalline $\mathrm{Zr}\left(\mathrm{R}-\mathrm{PO}_{3}\right)_{2}$ and $\mathrm{Zr}(\mathrm{R}-\mathrm{OPO})_{2}$ compounds ( $\mathrm{R}=$ organic radical). J. Inorg. Nucl. Chem. 1978, 40, 1113-1117. [CrossRef]

3. Dines, M.B.; DiGiacomo, P.M. Derivatized lamellar phosphates and phosphonates of M(IV) ions. Inorg. Chem. 1981, 20, 92-97. [CrossRef]

4. Rueff, J.M.; Poienar, M.; Guesdon, A.; Martin, C.; Maignan, A.; Jaffrès, P.A. Hydrothermal synthesis for new multifunctional materials: A few examples of phosphates and phosphonate-based hybrid materials. J. Solid State Chem. 2016, 236, 236-245. [CrossRef]

5. $\quad$ Evrard, Q.; Chaker, Z.; Roger, M.; Sevrain, C.M.; Delahaye, E.; Gallart, M.; Gilliot, P.; Leuvrey, C.; Rueff, J.M.; Rabu, P.; et al. Layered Simple Hydroxides Functionalized by Fluorene-Phosphonic Acids: Synthesis, Interface Theoretical Insights, and Magnetoelectric Effect. Adv. Funct. Mater. 2017, 27. [CrossRef]

6. Queffélec, C.; Petit, M.; Janvier, P.; Knight, D.A.; Bujoli, B. Surface Modification Using Phosphonic Acids and Esters. Chem. Rev. 2012, 112, 3777-3807. [CrossRef] [PubMed]

7. Sevrain, C.M.; Berchel, M.; Couthon, H.; Jaffrès, P.A. Phosphonic acid: Preparation and applications. Beilstein J. Org. Chem. 2017, 13, 2186-2213. [CrossRef] [PubMed]

8. Rueff, J.M.; Barrier, N.; Boudin, S.; Dorcet, V.; Caignaert, V.; Boullay, P.; Hix, G.B.; Jaffrès, P.A. Remarkable thermal stability of $\mathrm{Eu}(4$-phosphonobenzoate): Structure investigations and luminescence properties. Dalton Trans. 2009, 10614-10620. [CrossRef] [PubMed]

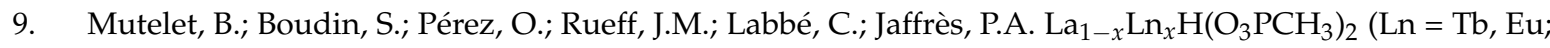
$0<x \leq 1$ ): An organic-inorganic hybrid with lanthanide chains and tunable luminescence properties. Dalton Trans. 2015, 44, 1186-1192. [PubMed]

10. Maeda, K. Metal phosphonate open-framework materials. Microporous Mesoporous Mater. 2004, 73, 47-55. [CrossRef]

11. Li, J.T.; Cao, D.K.; Akutagawa, T.; Zheng, L.M. $\mathrm{Zn}_{3}\left(4-\mathrm{OOCC}_{6} \mathrm{H}_{4} \mathrm{PO}_{3}\right)_{2}$ : A polar metal phosphonate with pillared layered structure showing SHG-activity and large dielectric anisotropy. Dalton Trans. 2010, 39, 8606-8608. [CrossRef] [PubMed]

12. Clearfield, A. Metal Phosphonate Chemistry. In Progress in Inorganic Chemistry; Karlin, K.D., Ed.; John Wiley \& Sons, Inc.: New York, NY, USA, 1998; pp. 371-510. ISBN 978-0-470-16648-2.

13. Benítez, I.O.; Bujoli, B.; Camus, L.J.; Lee, C.M.; Odobel, F.; Talham, D.R. Monolayers as Models for Supported Catalysts: Zirconium Phosphonate Films Containing Manganese(III) Porphyrins. J. Am. Chem. Soc. 2002, 124, 4363-4370. [CrossRef] [PubMed]

14. Ma, L.; Abney, C.; Lin, W. Enantioselective catalysis with homochiral metal-organic frameworks. Chem. Soc. Rev. 2009, 38, 1248-1256. [CrossRef] [PubMed]

15. Chen, X.; Peng, Y.; Han, X.; Liu, Y.; Lin, X.; Cui, Y. Sixteen isostructural phosphonate metal-organic frameworks with controlled Lewis acidity and chemical stability for asymmetric catalysis. Nat. Commun. 2017, 8, 2171. [CrossRef] [PubMed]

16. Mallouk, T.E.; Gavin, J.A. Molecular Recognition in Lamellar Solids and Thin Films. Acc. Chem. Res. 1998, 31, 209-217. [CrossRef]

17. Brousseau, L.C.; Mallouk, T.E. Molecular Design of Intercalation-Based Sensors. 1. Ammonia Sensing with Quartz Crystal Microbalances Modified by Copper Biphenylbis(phosphonate) Thin Films. Anal. Chem. 1997, 69, 679-687. [CrossRef]

18. Clearfield, A. Recent advances in metal phosphonate chemistry II. Curr. Opin. Solid State Mater. Sci. 2002, 6, 495-506. [CrossRef]

19. Berchel, M.; Gall, T.L.; Denis, C.; Hir, S.L.; Quentel, F.; Elléouet, C.; Montier, T.; Rueff, J.M.; Salaün, J.Y.; Haelters, J.P.; et al. A silver-based metal-organic framework material as a 'reservoir' of bactericidal metal ions. New J. Chem. 2011, 35, 1000-1003. [CrossRef]

20. Rueff, J.M.; Perez, O.; Caignaert, V.; Hix, G.; Berchel, M.; Quentel, F.; Jaffrès, P.A. Silver-Based Hybrid Materials from meta- or para-Phosphonobenzoic Acid: Influence of the Topology on Silver Release in Water. Inorg. Chem. 2015, 54, 2152-2159. [CrossRef] [PubMed]

21. Fanucci, G.E.; Krzystek, J.; Meisel, M.W.; Brunel, L.C.; Talham, D.R. Antiferromagnetic Resonance as a Tool for Investigating Magnetostructural Correlations: The Canted Antiferromagnetic State of $\mathrm{KMnPO}_{4} \cdot \mathrm{H}_{2} \mathrm{O}$ and a Series of Manganese Phosphonates. J. Am. Chem. Soc. 1998, 120, 5469-5479. [CrossRef] 
22. Rueff, J.M.; Caignaert, V.; Chausson, S.; Leclaire, A.; Simon, C.; Perez, O.; Le Pluart, L.; Jaffrès, P.A. meta-Phosphonobenzoic Acid: A Rigid Heterobifunctional Precursor for the Design of Hybrid Materials. Eur. J. Inorg. Chem. 2008, 2008, 4117-4125. [CrossRef]

23. Perez, O.; Bloyet, C.; Rueff, J.M.; Barrier, N.; Caignaert, V.; Jaffrès, P.A.; Raveau, B. Topochemical Route from Supramolecular to Hybrid Materials: Tetraphenylmethane-Based Tectons and Lanthanum Phosphonate Derivative. Cryst. Growth Des. 2016, 16, 6781-6789. [CrossRef]

24. Rueff, J.M.; Perez, O.; Pautrat, A.; Barrier, N.; Hix, G.B.; Hernot, S.; Couthon-Gourvès, H.; Jaffrès, P.A. Structural Study of Hydrated/Dehydrated Manganese Thiophene-2,5-diphosphonate Metal Organic Frameworks, $\mathrm{Mn}_{2}\left(\mathrm{O}_{3} \mathrm{P}-\mathrm{C}_{4} \mathrm{H}_{2} \mathrm{~S}-\mathrm{PO}_{3}\right) \cdot 2 \mathrm{H}_{2} \mathrm{O}$. Inorg. Chem. 2012, 51, 10251-10261. [CrossRef] [PubMed]

25. Rueff, J.M.; Caignaert, V.; Leclaire, A.; Simon, C.; Haelters, J.P.; Jaffrès, P.A. m-phosphonobenzoic acid and copper(II) as precursors of helical chain and lamellar hybrid materials. CrystEngComm 2009, 11, 556-559. [CrossRef]

26. Yücesan, G.; Zorlu, Y.; Stricker, M.; Beckmann, J. Metal-organic solids derived from arylphosphonic acids. Coord. Chem. Rev. 2018, 369, 105-122. [CrossRef]

27. Bulut, A.; Zorlu, Y.; Topkaya, R.; Aktaş, B.; Doğan, S.; Kurt, H.; Yücesan, G. Macrocyclic $\mathrm{Cu}(\mathrm{II})$-organophosphonate building block with room temperature magnetic ordering. Dalton Trans. 2015, 44, 12526-12529. [CrossRef] [PubMed]

28. Bladek, K.J.; Reid, M.E.; Nishihara, H.; Akhtar, F.; Gelfand, B.S.; Shimizu, G.K.H. Microsphere Assemblies via Phosphonate Monoester Coordination Chemistry. Chem. Eur. J. 2018, 24, 1533-1538. [CrossRef] [PubMed]

29. Hugot, N.; Roger, M.; Rueff, J.M.; Cardin, J.; Per $\times$ ez, O.; Caignaert, V.; Raveau, B.; Rogez, G.; Jaffrès, P.A. Copper-Fluorenephosphonate $\mathrm{Cu}\left(\mathrm{PO}_{3}-\mathrm{C}_{13} \mathrm{H}_{9}\right) \cdot \mathrm{H}_{2} \mathrm{O}$ : A Layered Antiferromagnetic Hybrid. Eur. J. Inorg. Chem. 2016, 2016, 266-271. [CrossRef]

30. Bloyet, C.; Rueff, J.M.; Caignaert, V.; Lohier, J.-F.; Cardin, J.; Jaffrès, P.A.; Raveau, B. Fluorenyl Zinc Phosphonate $\mathrm{Zn}\left(\mathrm{H}_{2} \mathrm{O}\right) \mathrm{PO}_{3}-\mathrm{C}_{13} \mathrm{H}_{9} \cdot \mathrm{H}_{2} \mathrm{O}$ : Hybrid Columnar Structure with Strong $\mathrm{C}-\mathrm{H} \cdots \pi$ Interactions. Z. Anorg. Allg. Chem. 2017, 643, 250-255. [CrossRef]

31. Cao, G.; Lee, H.; Lynch, V.M.; Mallouk, T.E. Synthesis and Structural Characterization of a Homologous Series of Divalent-Metal Phosphonates, $\mathrm{M}^{\mathrm{II}}\left(\mathrm{O}_{3} \mathrm{PR}\right) \cdot \mathrm{H}_{2} \mathrm{O}$ and $\mathrm{M}^{\mathrm{II}}\left(\mathrm{HO}_{3} \mathrm{PR}\right)$. Inorg. Chem. 1988, 27, 2781-2785. [CrossRef]

32. Merrill, C.A.; Cheetham, A.K. Inorganic-Organic Framework Structures; M(II) Ethylenediphosphonates $(\mathrm{M}=\mathrm{Co}, \mathrm{Ni}, \mathrm{Mn})$ and a $\mathrm{Mn}(\mathrm{II})$ Ethylenediphosphonato-phenanthroline. Inorg. Chem. 2007, 46, 278-284. [CrossRef] [PubMed]

33. Tang, S.F.; Li, L.J.; Lv, X.X.; Wang, C.; Zhao, X.B. Tuning the structure of metal phosphonates using uncoordinating methyl group: Syntheses, structures and properties of a series of metal diphosphonates. CrystEngComm 2014, 16, 7043-7052. [CrossRef]

34. Brown, I.D.; Altermatt, D. Bond-valence parameters obtained from a systematic analysis of the Inorganic Crystal Structure Database. Acta Crystallogr. Sect. B Struct. Sci. 1985, 41, 244-247. [CrossRef]

35. Spackman, M.A.; Jayatilaka, D. Hirshfeld surface analysis. CrystEngComm 2009, 11, 19-32. [CrossRef]

36. McKinnon, J.J.; Spackman, M.A.; Mitchell, A.S. Novel tools for visualizing and exploring intermolecular interactions in molecular crystals. Acta Crystallogr. Sect. B Struct. Sci. 2004, 60, 627-668. [CrossRef] [PubMed]

37. Spackman, M.A.; McKinnon, J.J. Fingerprinting intermolecular interactions in molecular crystals. CrystEngComm 2002, 4, 378-392. [CrossRef]

38. Wolff, S.K.; Grimwood, D.J.; McKinnon, J.J.; Turner, M.J.; Jayatilaka, D.; Spackman, M.A. CrystalExplorer; University of Western Australia: Crawley, WA, Australia, 2012.

39. Demadis, K.D.; Anagnostou, Z.; Panera, A.; Mezei, G.; Kirillova, M.V.; Kirillov, A.M. Three-component 1D and 2D metal phosphonates: Structural variability, topological analysis and catalytic hydrocarboxylation of alkanes. RSC Adv. 2017, 7, 17788-17799. [CrossRef]

40. Carlin, R.L. Magnetochemistry; Springer: Berlin/Heidelberg, Germany, 1986; ISBN 978-3-642-70735-3.

(C) 2018 by the authors. Licensee MDPI, Basel, Switzerland. This article is an open access article distributed under the terms and conditions of the Creative Commons Attribution (CC BY) license (http:/ / creativecommons.org/licenses/by/4.0/). 